\title{
Prevalence of Hepatitis B and C Infection in Patients with Rheumatoid Arthritis in Marrakesh
}

\author{
Marakeș'te Romatizmal Hastalıkları Olan Hastalarda Hepatit B ve C Enfeksiyon Sıklığı
}

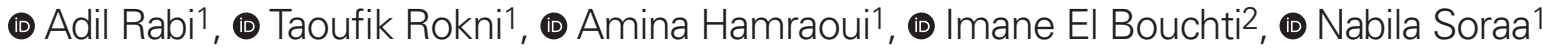 \\ ${ }^{1}$ Centre Hospitalier Universitaire Mohammed VI Marrakech, Department of Microbiology, Marrakech, Morocco \\ ${ }^{2}$ Centre Hospitalier Universitaire Mohammed VI Marrakech, Department of Rheumatology, Marrakech, Morocco
}

\begin{abstract}
Objectives: Although there is no difference in frequency of hepatitis $B$ virus (HBV) and hepatitis $C$ virus $(\mathrm{HCV})$ infection in patients with rheumatoid arthritis (RA) in general population, multicenter studies are needed across the country to support this idea. The aim of this study is to invastigate the prevalence of HBV and HCV infections in RA patients.

Materials and Methods: This study is carried out for 3 years and is a retrospective and descriptive study. In this study, we recorded the clinical and immunological characteristics of the patients as well as immunosuppressive treatments and immune status responses to HBV and HCV.

Results: One hundred fifty-three RA patients were included in this study. (83.5\%) of the patients were female and the mean age was $50 \pm 13.6 .53 \%$ had a history of tuberculosis disease infeciton. The average duration of disease progression was 4.1 years. These were erosive RA present in $68 \%$ of cases and seropositive in $83.5 \%$. Activity was severe in $8.7 \%$ of cases. Out of 153 patients, 3 were hepatitis B surface antigen positive, 3 were anti-HBs antibodies positive, and 19 were anti-HBc antibodies positive.

Conclusion: New cases will be identified in screening, even in populations where viral hepatitis is not endemic. In patients with immunodeficiency, early diagnosis is essential given the severity of hepatitis $B$ and $C$ infection.

Keywords: HVB, HVC, rheumatoid arthritis
\end{abstract}

OZZ

Amaç: Genel popülasyondaki romatoid artrit'li (RA) hastalarda hepatit $B$ virüsü $(H B V)$ ve hepatit $C$ virüsü $(H C V)$ enfeksiyonlarının görülme sıklğı farklı olmamasına rağmen, bu fikri desteklemek için ülke çapında çok merkezli çalışmalara intiyaç vardır. Bu çalışmanın amacı RA hastalarında HBV ve HCV enfeksiyonlarının prevalansını araştırmaktır.

Gereç ve Yöntemler: Bu çalışma, 3 yıl boyunca yürütülmüş olup geriye dönük ve tanımlayıcı bir çalışmadır. Çalışmamızda, hastaların klinik ve immünolojik özellikleri ile birlikte, immünosüpresif tedaviler ve HBV ve HCV'ye karşı immün yanıtları kaydedilmiştir.

Bulgular: Bu çalışmaya 153 RA hastası dahil edildi. Hastaların $\% 83,5$ 'ü kadındı ve yaş ortalamaları $50 \pm 13$ idi. \%6,53'ünde tüberküloz enfeksiyonu öyküsü vardı. Ortalama hastalık ilerlemesi süresi 4,1 yıldı. Bunlar olguların \%68'inde erozif RA mevcuttu ve $\% 83,5$ 'i seropozitifti. Olguların \%8,7'sinde aktivite şiddetliydi. Yüz elli üç hastanın 3 'ünde hepatit B yüzey antijeni pozitif, 3 'ünde antiHBs antikoru pozitif, 19'unda anti-HBc antikoru pozitifti.

Sonuç: Viral hepatitin endemik olmadığı popülasyonlarda bile taramada yeni olgular tanımlanacaktır. Immün yetmezliği olan hastalarda hepatit $B$ ve $C$ enfeksiyonunun ciddiyeti göz önüne alındığında, erken tanı şarttır.

Anahtar Kelimeler: HVB, HVC, romatoid artrit

Rabi A, Rokni T, Hamraoui A, El Bouchti I, Soraa N. Prevalence of Hepatitis B and C Infection in Patients with Rheumatoid Arthritis in Marrakesh. Viral Hepat J. 2020;26:28-31. 


\section{Introduction}

Rheumatoid arthritis (RA) is systemic inflammatory rheumatic diseases with a complex and partially understood etiology. Several pathogens have been debated to trigger the initial immune response necessary for development of RA in a genetically susceptible host (1). Numerous viruses have been associated with the development of inflammatory arthritis, including the hepatitis viruses [hepatitis B virus (HBV) and $\mathrm{HCV}$ ], human immunodeficiency virus, parvovirus B19, human T-cell lymphotropic virus-1, and alpha viruses (2).

Hepatitis infections are widespread diseases in the world, and an estimated 2 billion people have been infected with HBV and 170 million people have been infected with HCV (3). Immunosuppressive therapy, especially tumor necrosis factor-alpha inhibitors and anti-B cell therapy can induce viral reactivation in patients with concurrent HBV infection (4). Therefore, screening for $\mathrm{HBV}$ and HCV infection is recommended for patients who receive immunosuppressive therapy $(2,4)$.

The prevalence of HBV and HCV infections in the general population may differ according to geographic regions. In Morocco, HBV and HCV prevalence was reported to be $1.81 \%$ and $1.58 \%$, respectively (5). Although the frequency of $\mathrm{HBV}$ and $\mathrm{HCV}$ infections is not expected to be different in RA (6) patients from the general population, multicenter countrywide studies are required to support this idea. The purpose of this study was to explore the prevalence of HBV and HCV infections in RA patients.

\section{Materials and Methods}

\section{Study Population and Design}

This is a retrospective and descriptive study, carried out over a period of 3 years between January 2015 and July 2018, conducted in collaboration between the Bacteriology-Virology laboratory and the rheumatology department of the Mohammed VI University Hospital of Marrakesh. This study included 153 cases of RA, diagnosed with RA according to the ACR (RA classification criteria) eular 2010 criteria.

Clinical and laboratory data [serum aminotransferase aspartate aminotransferase (AST), alanine aminotransferase (ALT), hepatitis B surface antigen ( $\mathrm{HBsAg})$, anti-HBc, anti-HBs, anti-HCV, hepatitis $\mathrm{B}$ e antigen ( $\mathrm{HBeAg}$ ), anti-HBe, HBV-DNA, and HCV-RNA] were evaluated according to patient medical records. ALT, AST levels $>40$ $\mathrm{IU} / \mathrm{mL}$ were considered high transaminase levels.

This study has been approved by the Ethics Committee of Mohammed VI Hospital in Marrakech (approval number: 28/04, date: 14/04/2018). Informed consent was obtained from the patients.

\section{Serological Tests}

Serological tests were detected using chemiluminescence microparticle immunoassay on the Abbott Architect i1000. Patients with positive HBsAg or anti-HCV results were additionally tested for HBV-DNA or HCV-RNA in serum. HBV-DNA and HCV-RNA were tested by a real-time polymerase chain reaction (RT-PCR)based method.

\section{Statistical Analysis}

Data analysis was performed using version 14 SPSS (Statistical Package for the Social Science Program Inc., Chicago. Illinois, USA).
Descriptive statistical analyses were presented as the range, mean and standard deviation for quantitative variables.

\section{Results}

In this study, 153 RA patients were included, (83.5\%) were female and the average age was $50 \pm 13$ (range: $38-88$ years old), $6.53 \%$ of patients had a history of tuberculosis disease (10 cases).

The average duration of disease progression was 4.1 years. These were erosive RA in $68 \%$ of cases and seropositive in $83.5 \%$. Activity was severe in $8.7 \%$ of cases, while $26.6 \%$ of patients were in remission according to Disease Activity Index 28 vs.

Therapeutically, $71.8 \%$ were on Methotrexate while 16.5\% on Rituximab and $1 \%$ on Tociluzimab. Long-term corticosteroid therapy was prescribed in $81.6 \%$ of patients.

Among a total of 153 patients, HBsAg was positive in 3 (1.96\%) patients, and negative in 150 (98.04\%) patients, Anti-HBs antibodies were positive 24 (15.68\%) patients, anti-HBC antibodies was positive in $19(12.41 \%)$ patients.

The interpretation of Hepatitis B serologic test results show that: 3 Patients had Hepatitis B infection, 10 patients had successful vaccination, 14 patients had resolved hepatitis $B$ infection (immune to reinfection), and in 2 patients anti-HBc was only positive and the other markers were negative.

In the HBsAg (+) and anti-HBc (+) group, (2/3) of patients had a negative $\mathrm{HBeAg}(-)$ and a positive anti-HBe $(+)$, and (1/3) of patients had a positive $\mathrm{HBeAg}(+)$ and a negative anti-HBe (-). All patients had a positive HBV-DNA results and a high AST and/or ALT levels, Table 1.

In the anti-HBc (+), HBsAg (-) and anti-HBs (-) group: all patient had a negative $\mathrm{HBeAg}$ and a negative anti-HBe. But (1/2) of patients had a positive HBV-DNA results and high ALT and AST level, Table 1.

The screen for hepatitis $\mathrm{C}$ (anti-HCV) was negative in all patients.

\section{Discussion}

Hepatitis virus infections are an important issue because of the difficulties in the diagnostic and therapeutic approach of rheumatic diseases. HBV and HCV infections may present with several rheumatic manifestations and may have a role in the etiopathogenesis of autoimmune diseases (5). Otherwise, immunosuppressive drugs are commonly used in the

Table 1. Completeness of hepatitis screening

\begin{tabular}{|l|l|l|}
\hline \multicolumn{3}{|l|}{ Table 1. Completeness of hepatitis screening } \\
\hline & Number & Percentage \\
\hline HBsAg (+) & 3 & 1.96 \\
\hline HBsAg (-) & 150 & 98.04 \\
\hline Anti-HBc (+) & 19 & 12.41 \\
\hline Anti-HBc (-) & 134 & 87.58 \\
\hline Anti-HBs (+) & 24 & 15.68 \\
\hline Anti-HBs (-) & 129 & 84.31 \\
\hline Anti-HCV (+) & 0 & 0 \\
\hline Anti-HCV (-) & 153 & 100 \\
\hline $\begin{array}{l}\text { HBsAg: Hepatitis B surface antigen, HBc: hepatitis B core, HCV: Hepatitis C } \\
\text { virus }\end{array}$ &
\end{tabular}


management of rheumatic diseases and were shown to induce viral reactivation in HBV- and HCV - positive patients, and in most instances, flares are asymptomatic. Several case reports have documented HBV reactivation in inactive HBV carriers treated with methotrexat and biologic agents, including infliximab $(7,8)$, etanercept (9), adalimumab (10), and rituximab $(11,12)$. Therefore, ACR recommends screening for $\mathrm{HBV}$ and $\mathrm{HCV}$ before non-biologic or biologic immunosuppressive therapy $(4,12)$.

$\mathrm{HBsAg}$ is the best assay screening for HBV infection but is sometimes negative and other marker such as anti-HBc should be examined (13). In this study prevalence of anti-HBC is higher than prevalence of HBsAg for meticulous evaluation of HBV infection in RA patients, because isolated anti-HBc positive is a risk factor for reactivation of HBV (14).

Isolated positive anti-HBc can be seen in three conditions that the first is acute infections, second chronic hepatitis which may be progressive and third improved and therefore type 1 and type 2 after immunosuppressive therapy are at risk for reactivation and fulminant hepatitis (15).

Patients who had anti-HBc positive treated with immunosuppressive drugs, reactivation of hepatitis may be occured so evaluation every 6-month for hepatitis had indicated until don't delayed is prophylaxis (16).

Before chemotherapy, patients should be screened for serological HBV markers and HBV-DNA levels in case of HBsAg and/or anti-HBc positivity. HBV vaccination is recommended in seronegative patients. In HBsAg-positive patients, pre-emptive treatment should be initiated whatever the HBV-DNA levels and continued for 6-12 months after immunosuppressive therapy is done. Entecavir or tenofovir are preferable in patients with an initial viral load $42000 \mathrm{IU} / \mathrm{mL}$. ALT and HBV-DNA levels should be closely monitored in anti-HBc positive patients with or without anti-HBs, and antiviral therapy should be started when HBV reactivation is confirmed. Anti-HBs titers should be monitored closely in anti-HBs positive patients because a decrease in anti-HBs can precede seroreversion. Therapy is not needed as long as anti-HBs titers are protective (17).

Detection of serum anti-HCV antibodies is an indicative of past or active infection, but viraemia assesses by reverse transcription RT-PCR is a better sensitive indicator of chronic HCV infection than serology (18).

In this study we didn't find any case of hepatitis C, hence, some patients infected with HCV could have been missed in this study, because patients were systematically screened for anti-HCV antibodies with a search for HCV-RNA only in cases of seropositivity. However, this methodology was used because the prevalence of patients negative for HCV by serology, but positive by RT-PCR seems to be very low. This joins the results of Cacoub et al. (19), who did not find any patient with RA in a sample of 1614 patients with chronic HCV infection.

Only the use of rituximab and high dose steroids were significantly associated with high risk of developing HCV. Rituximab as a single agent or in combination with steroids or other chemotherapeutic agents is the drug associated with the highest risk of HBV reactivation, in persons with chronic or past HBV infection (20). Rituximab had also been described to be an important cause of $\mathrm{HCV}$. Rituximab-based therapy causes a profound depletion of Bcells and a marked reduction of T-cells, mainly CD4+ cells, and has been reported to cause reactivation of other viruses, including cytomegalovirus and herpes simplex virus (20). Steroids are known to cause a rapid depletion and apoptosis of circulating T-cells. Previous studies revealed that steroids stimulate $\mathrm{HCV}$ replication in vitro, and there are clinical reports that patients treated with high dose steroids had an increase in HCV-RNA levels (20).

Hepatitis B and C infections are widespread diseases in the world, and their prevalence in the general population differs according to geographic regions ranging from over 10\% in Asia to under $0.5 \%$ in the United states and Northern Europe (21). In another point, hepatitis infection may present with numerous extrahepatic manifestations, and patients often apply to different specialities according to the predominant clinical feature. Patients joint symptoms [(of the most common extre-articular findings) may be believed to be associated with $\mathrm{HBV}$ or $\mathrm{HCV}$ in certain times. So, the real prevalence of these infection was reported as $0.12 \%$ and $0.86 \%$ in early arthritis]. In addition, $\mathrm{HCV}$ prevalence was reported as $0.65 \%$ in 309 RA patients in France (21). these values were not greater than expected based on data from the general population in the same geographic area. In another study from China, the prevalence of HBsAg was shown as $12.8 \%$ in the general population, $9.6 \%$ in RA patients $(2,22,23)$.

In our country, HBV and HCV prevalence was reported as $1.81 \%$ and $1.58 \%$ in the general population (24). In our study, we found similar HBsAg prevalence in RA patients compared to the general population. On the other hand, we showed a lower prevalence of anti-HCV antibodies seropositivity in RA patients according to our national data.

\section{Study Limitations}

There are also several limitations to our study, foremost being its retrospective nature, Baseline HBV and HCV testing was missing in some patients, who were excluded from the study, the second limitation we did not screen our patients for HCV-RNA, resulting in underestimation of the incidence of $\mathrm{HCV}$, third the small number of patients.

\section{Conclusion}

Even in populations where viral hepatitis is not endemic, new cases will be identified on screening. Given the serioussness of hepatitis $\mathrm{B}$ and $\mathrm{C}$ infection in immuno-compromised patients, early identification is essential. For the best outcome, anti-viral treatment should be initiated prior to antirheumatic treatment. Greater awareness of asymptomatic current or past hepatitis B or $\mathrm{C}$ infection is necessary of all cases are to be recognized. This premise applies not only for RA but also for all chronic inflammatory diseases treated using immunosuppressive drugs.

\section{Ethics}

Ethics Committee Approval: This study has been approved by the Ethics Committee of Mohammed VI Hospital in Marrakech (approval number: 28/04, date: 14/04/2018).

Informed Consent: Informed consent was obtained from the patients.

Peer-review: Externally peer-reviewed. 


\section{Authorship Contributions}

Data Collection and/ or Processing: A.R., N.S., Analysis and/or Interpretation: T.R., A.H., Literature Search: A.R., I.B., N.S., Writing Manuscript: A.R.

Conflict of Interest: The authors claim that they have no conflict of interest.

Financial Disclosure: The authors declared that this study received no financial support.

\section{References}

1. Oliver JE, Silman AJ. Risk factors for the development of rheumatoid arthritis. Scand J Rheumatol. 2006;35:169-174.

2. Yılmaz N, Karadağ Ö, Kimyon G, Yazıcı A, Yılmaz S, Kalyoncu U, Kaşifoğlu T, Hakan Temiz H, Baysal B, Tözün N. Prevalence of hepatitis $B$ and $C$ infections in rheumatoid arthritis and ankylosing spondylitis: A multicenter countrywide study. Eur J Rheumatol. 2014;1:51-54.

3. Pyrpasopoulou A, Douma $S$, Vassiliadis $T$, Chatzimichailidou $S$, Triantafyllou A, Aslanidis S. Reactivation of chronic hepatitis B virus infection following rituximab administration for rheumatoid arthritis. Rheumatol Int. 2011;31:403-404.

4. Saag KG, Teng GG, Patkar NM, Anuntiyo J, Finney C, Curtis JR, Paulus HE, Mudano A, Pisu M, Elkins-Melton M, Outman $\mathrm{R}$, Allison JJ, Almazor MS, Bridges SL Jr., Chatham WW, Hochberg M, Maclean C, Mikuls T, Moreland LW, O'dell J, Turkiewicz AM, Furst DE. American College of Rheumatology 2008 recommendations for the use of nonbiologic and biologic disease-modifying antirheumatic drugs in rheumatoid arthritis. Arthritis Rheum. 2008:59:762-784.

5. Tozun N, Ozdogan O, Cakaloglu Y, Idilman R, Karasu Z, Akarca U, Kaymakoglu S, Ergonul O. Seroprevalence of hepatitis B and C virus infections and risk factors in Turkey: a fieldwork TURHEP study. Clin Microbiol Infect. 2015;21:1020-1026.

6. Guennoc X, Narbonne V, Joulin SJ, Pensec VP, Dougados M, Daures JP, Saraux A. Is screening for Hepatitis B and Hepatitis $\mathrm{C}$ useful in patients with recent onset polyarthritis? The ESPOIR cohort study. J Rheumatol. 2009;36:1407-1413.

7. Esteve M, Saro C, Gonza'lez-Huix F, Suarez F, Forne' M, Viver JM. Chronic hepatitis B reactivation following infliximab therapy in Crohn's disease patients: need for primary prophylaxis. Gut. 2004;53:1363-1365.

8. Chung SJ, Kim JK, Park MC, Park YB, Lee SK. Reactivation of hepatitis $B$ viral infection in inactive HBsAg carriers following antitumor necrosis factor-alpha therapy. J Rheumatol. 2009;36:24162420.

9. Kuroda T, Wada $Y$, Kobayashi D, Sato H, Murakami S, Nakano M, Narita T. Effect of etanercept and entecavir in a patient with rheumatoid arthritis who is a hepatitis B carrier: a review of the literature. Rheumatol Int. 2012;32:1059-1063.

10. Verhelst X, Orlent H, Colle I, Geerts A, De Vos M, Van Vlierberghe $H$. Subfulminant hepatitis B during treatment with adalimumab in a patient with rheumatoid arthritis and chronic hepatitis B. Eur J Gastroenterol Hepatol. 2010;22:494-499.
11. Dervite I, Hober D, Morel P. Acute hepatitis B in a patient with antibodies to hepatitis $\mathrm{B}$ surface antigen who was receiving rituximab. N Engl J Med. 2001;4;344:68-69.

12. Westhoff $T H$, Jochimsen $F$, Schmittel A, Stoffler-Meilicke $M$, Schafer JH, Zidek W, Gerlich WH, Thiel E. Fatal hepatitis B virus reactivation by an escape mutant following rituximab therapy. Blood. 2003;102:1930.

13. Roche B, Samuel D. The difficulties of managing severe hepatitis B virus reactivation. Liver Int. 2011;31(Suppl 1):104-110.

14. Tanaka E, Urata Y. Risk of hepatitis B reactivation in patients treated with tumor necrosis factor- $\alpha$ inhibitors. Hepatol Res. 2012;42:333339.

15. Ryu HH, Lee EY, Shin K, Choi IA, Lee YJ, Yoo B, Park MC, Park YB, Bae SC, Yoo WH, Kim SI, Lee EB, Song YW. Hepatitis B virus reactivation in rheumatoid arthritis and ankylosing spondylitis patients treated with anti-TNF $\alpha$ agents: a retrospective analysis of 49 cases. Clin Rheumatol. 2012;31:931-936.

16. Alishiri GH, Ghorbani GA, Ahmed S. Prevalence of hepatitis $B$ infection in Rheumatoid Arthritis patients. Pak J Biol Sci. 2013;16:747-750.

17. Eun Y, Kim IY, Jeong H, Kim H, Lee J, Choi MS, Koh E, Cha HS Disease Characteristics and Change in Arthritis Activity according to Treatment in Hepatitis B Surface Antigen-positive Rheumatoid Arthritis Patients: a Retrospective Chart Review Study. J Korean Med Sci. 2018;33:e168.

18. Tung CH, Lai NS, Li CY, Tsai SJ, Chen YC, Chen YC. Risk of rheumatoid arthritis in patients with hepatitis $C$ virus infection receiving interferon-based therapy: a retrospective cohort study using the Taiwanese national claims database. BMJ Open. 2018;8:e021747.

19. Cacoub P, Renou C, Rosenthal E, Cohen P, Loury I, Loustaud-Ratti $V$, Yamamoto AM, Camproux AC, Hausfater P, Musset L, Veyssier P, Raguin G, Piette JC. Extrahepatic manifestations associated with hepatitis C virus infection. Medicine (Baltimore). 2000;79:4756.

20. Lin KM, Lin JC, Tseng WY. Rituximab-induced hepatitis C virus reactivation in rheumatoid arthritis. J Microbiol Immunol Infect. 2013;46:65-67.

21. Maillefert JF, Muller G, Falgarone G, Bour JB, Ratovohery D, Dougados M, Tavernier C, Breban M. Prevalence of hepatitis C virus infection in patients with rheumatoid arthritis. Ann Rheum Dis. 2002;61:635-637.

22. Zerrak A, Bour JB, Tavernier C, Dougados M, Maillefert JF Usefulness Usefulness of routine hepatitis C virus, hepatitis B virus, and parvovirus B19 serology in the diagnosis of recentonset inflammatory arthritides. Arthritis Rheum. 2005;53:477478.

23. Hsu CS, Lang HC, Huang KY, Lin HH, Chen CL. Association of rheumatoid arthritis and hepatitis $\mathrm{b}$ infection a nationwide nested case-control study from 1999 to 2009 in Taiwan. Medicine (Baltimore). 2016;95:e3551.

24. Benjelloun S, Benani A. I'institut pasteur du maroc au cœur de la problematique: Infections par les virus des hepatites $B$ et $C$. Lettre Pasteur. 2016;4:11-12. 